\title{
Therapeutic plasma exchange for severe hyperlipidaemia in a patient with poorly controlled diabetes
}

\author{
Daniela Hermelin, ${ }^{1}$ Peyman Dinarvand, ${ }^{1}$ Armin Krvavac, ${ }^{2}$ Douglas Blackall ${ }^{1}$
}

'Department of Pathology, Saint Louis University School of Medicine, Saint Louis, Missouri, USA

${ }^{2}$ Department of Internal Medicine, Saint Louis University School of Medicine, Saint Louis, Missouri, USA

Correspondence to Dr Douglas Blackall, douglas.blackall@health.slu.edu

Accepted 14 March 2018

\section{DESCRIPTION}

Hypertriglyceridaemia (HTG) is a common condition in the USA and is often caused or exacerbated by uncontrolled diabetes mellitus (DM), obesity and other metabolic disorders. It is usually asymptomatic until triglycerides exceed $1000 \mathrm{mg} /$ dL. Signs include gastrointestinal pain, nausea, vomiting and dyspnoea. In type I DM, insulin deficiency leads to an inhibition of lipoprotein lipase (LpL). ${ }^{1}$ Control with insulin restores LpL function and reduces triglyceride levels. While initiating glucose control, therapeutic plasma exchange (TPE) can be used adjunctively, with intravenous insulin, to rapidly decrease triglyceride levels and prevent acute pancreatitis.

A man of 30 with poorly controlled type I DM, secondary to gallstone pancreatitis, presented for treatment of abdominal pain, nausea, vomiting and HTG. His father also has HTG, but no genetic testing for inherited lipid disorders has been pursued. The patient's initial glucose level was $335 \mathrm{mg} / \mathrm{dL}$ and his HbA1c was 14.2\%. His lipid panel included a triglyceride level $>3360 \mathrm{mg} / \mathrm{dL}$,

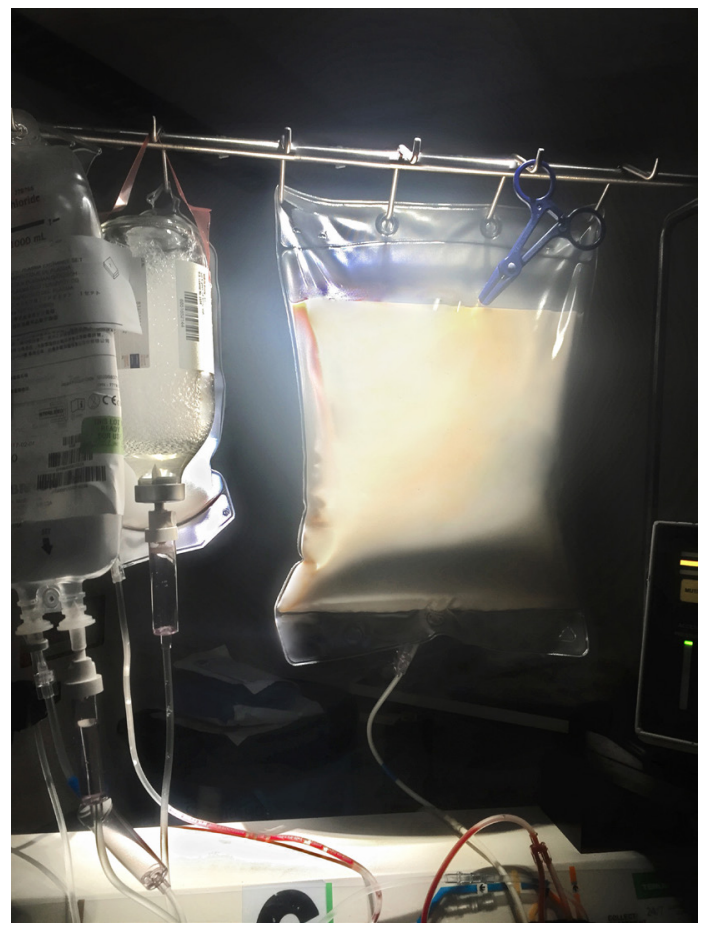

Figure 1 Milky white plasma collected in a plasmapheresis procedure for severe hypertriglyceridaemia. cholesterol of $1435 \mathrm{mg} / \mathrm{dL}$, low-density lipoprotein $>279 \mathrm{mg} / \mathrm{dL}$ and high-density lipoprotein $<5 \mathrm{mg} /$ $\mathrm{dL}$. The patient had evidence of ketoacidosis, with a $\beta$-hydroxybutyrate of $2.73 \mathrm{mg} / \mathrm{dL}(0.02-0.27)$ and a lactic acid of $8.8 \mathrm{mmol} / \mathrm{L}(0.5-2.2)$. A mild elevation of his lipase level was also noted at 93 units/L (8-78). His ionised calcium was $1.08 \mathrm{mmol} / \mathrm{L}$ (1.191.34). An abdominal CT scan revealed pancreatic fat stranding consistent with pancreatitis. In the first 12 hours of his admission, the patient was treated with intravenous fluids, an insulin drip (to maintain blood glucose levels between 140 and $180 \mathrm{mg}$ / $\mathrm{dL}$ ), fasting and TPE (1.0 plasma volume with 5\% albumin replacement).

The patient underwent one TPE procedure, and his plasma had a milky white appearance (figure 1). Thirty minutes into the procedure, he had nausea and tingling consistent with hypocalcaemia. The procedure was paused briefly, and the citrate anticoagulant inlet was slowed. The procedure was resumed when the tingling subsided and was completed without complication. In fact, the patient was very satisfied with the procedure and stated that he 'felt wonderful and had never had this feeling in the last three years.' His immediate postprocedure triglyceride level was $874 \mathrm{mg} / \mathrm{dL}$, which declined to $677 \mathrm{mg} / \mathrm{dL} 5$ hours later. Twenty-four hours after the procedure, his triglyceride level was $533 \mathrm{mg} / \mathrm{dL}$ (last value obtained). The patient was discharged with fenofibrate, placed on a low-fat diet and was followed by an endocrinologist.

Learning points

Hypertriglyceridaemia is a common condition in the USA, which is often caused or exacerbated by uncontrolled diabetes mellitus, but is usually asymptomatic until triglyceride levels exceed $1000 \mathrm{mg} / \mathrm{dL}$.

- While initiating glucose control, therapeutic plasma exchange can be used adjunctively, with intravenous insulin, to rapidly decrease triglyceride levels and prevent acute pancreatitis.

- The 2016 American Society for Apheresis Guidelines categorise hypertriglyceridaemic pancreatitis as a category III indication (ie, optimum role of apheresis therapy is not established; decision-making should be individualised). 
As advocated by the Endocrine Society, the therapeutic approach to HTG includes a combination of lifestyle modifications (diet, exercise, weight reduction) and medications (fibrates, N-3 fatty acids, niacin). ${ }^{2}$ However, TPE is considered a means to prevent or treat pancreatitis associated with severe HTG. ${ }^{3}$ The American Society for Apheresis categorises hypertriglyceridaemic pancreatitis as a category III indication (ie, optimum role of apheresis therapy is not established; decision-making should be individualised) with a grade $2 \mathrm{C}$ recommendation (ie, weak, with low-quality evidence). ${ }^{3}$ However, as this case clearly demonstrates, TPE can be an effective adjunctive therapy in patients with uncontrolled DM, HTG and symptoms of acute pancreatitis, and is the most rapid method available for acutely lowering triglyceride levels.

Acknowledgements The authors gratefully acknowledge Katherine Robbins who participated in the care of this patient during his plasmapheresis procedure.

Contributors Conception and design: DH, DB. Acquisition of data and analysis: $D H, P D, A K, D B$. Interpretation of data: PD, AK, DB. Drafting the article and revising it critically for important intellectual content: DH, DB. Final approval of the version published: DH, PD, AK, DB. Agreement to be accountable for the article and to ensure that all questions regarding the accuracy and integrity of the article are investigated and resolved: $\mathrm{DH}, \mathrm{PD}, \mathrm{AK}, \mathrm{DB}$.

Funding The authors have not declared a specific grant for this research from any funding agency in the public, commercial or not-for-profit sectors.

Competing interests None declared.

Patient consent Obtained.

Provenance and peer review Not commissioned; externally peer reviewed.

(c) BMJ Publishing Group Ltd (unless otherwise stated in the text of the article) 2018. All rights reserved. No commercial use is permitted unless otherwise expressly granted.

\section{REFERENCES}

1 Hassing HC, Surendran RP, Mooij HL, et al. Pathophysiology of hypertriglyceridemia. Biochim Biophys Acta 2012;1821:826-32.

2 Berglund L, Brunzell JD, Goldberg AC, et al. Evaluation and treatment of hypertriglyceridemia: an Endocrine Society clinical practice guideline. J Clin Endocrinol Metab 2012;97:2969-89.

3 Schwartz J, Padmanabhan A, Aqui N, et al. Guidelines on the use of therapeutic apheresis in clinical practice-evidence-based approach from the writing committee of the american society for apheresis: the seventh special issue. J Clin Apher 2016;31:149-338

Copyright 2018 BMJ Publishing Group. All rights reserved. For permission to reuse any of this content visit http://group.bmj.com/group/rights-licensing/permissions.

BMJ Case Report Fellows may re-use this article for personal use and teaching without any further permission.

Become a Fellow of BMJ Case Reports today and you can:

- Submit as many cases as you like

- Enjoy fast sympathetic peer review and rapid publication of accepted articles

Access all the published articles

Re-use any of the published material for personal use and teaching without further permission

For information on Institutional Fellowships contact consortiasales@bmjgroup.com

Visit casereports.bmj.com for more articles like this and to become a Fellow 